\title{
The Effects of COVID-19 on Native Americans
}

\section{Phyllis M Weaver RPh*}

Certified Health Coach, Owner Discover Ultimate Health, LLC Discover Ultimate Health, LLC Health Coach Institute, USA

*Corresponding Author: Phyllis M Weaver, Certified Health Coach, Owner Discover Ultimate Health, LLC Discover Ultimate Health, LLC Health Coach Institute, USA.
Received: October 21, 2020

Published: January 16, 2021

(C) All rights are reserved by Phyllis M

Weaver.

\begin{abstract}
There is a disproportionate number of COVID-19 cases among Native Americans, including exposures, hospitalizations, and deaths. Due to substandard healthcare, housing, and poverty, American Indians and Alaska Natives have a higher number of preexisting high-risk conditions to make them more susceptible to the coronavirus. Research shows the reason why and how improvements are necessary for collecting and reporting demographic data..
\end{abstract}

Keywords: COVID-19; DNA; RNA; Housing

\section{What is Covid-19?}

COVID-19, a potentially deadly disease, is caused by the SARS CoV-2 virus (Severe Acute Respiratory Syndrome Coronavirus 2). The trillions of species infect all types of organisms, including animals, plants, and bacteria. They carry genetic material from either deoxyribonucleic acid (DNA) or ribonucleic acid (RNA), the long helical molecules. They reproduce, mutate, and evolve through natural selection, although they do not contain a cellular structure that is necessary for life. At the basic level, viruses are proteins. They consist of two or three parts: a helical molecule, a protein coat, and sometimes a viral envelope of fat. Some scientists consider viruses to be a type of lifeform because they can replicate on their own. Some scientists disagree because viruses depend on a host organism for replication. Each virus has a host range, and the virus can sometimes jump, which is "spillover." That is what happened with Sars-CoV2 ( Covid-19 beta coronavirus) 2019, which was initially a bat virus that jumped to humans. [CDC] Because RNA viruses are more unstable, mutate, and spillover more, and it can be challenging to make the vaccine.
How is it transmitted? People breathe in viral droplets, in aerosols, or by touching the nose, eyes, and mouth. Once inside the body, the virus enters the respiratory tract. It starts replicating itself. When the virus attaches itself to a cell, a series of chemical events occur, leading to inflammation of membranes, and all organs are susceptible to attack. The problem comes when people have been infected and do not know because of the long incubation period (214 days). Some people are infectious before symptoms start or positive but asymptomatic, which is hugely problematic for high-risk obese individuals over 65 years old, and have a chronic disease.

Fewer children have been affected than adults. Currently, the death toll is globally is over 1 million since the first case less than a year ago. According to John Hopkins University data, the global death toll from COVID-19 was 1,000,555 as of Monday evening, September 28, 2020, in the September 29, 2020 issue of Pharmacy Today. Worldwide at least 33 million people have tested positive for SARS-CoV-2, though the actual number is likely much higher. About 250,000 people worldwide test positive every day. In the United, some 7.1 million people have tested "positive" daily, and over 204,000 Americans have died, which is nearly 900 deaths per day. 
Unfortunately, after plateauing in certain Midwestern and Mountain West states, new cases are on the rise. As of October 20, 2020, there are 8,188,585 cases ( $+60,061$ new cases) and 219,499 total deaths (+513 new deaths). Out of all of the cases reported in the United States, there are significantly higher cases of people of color, including Native Americans. According to the Centers for Disease Control, American Indian and Alaska Native people are 5.3 times more likely than white people to be hospitalized due to COVID-19. They have a disproportionately higher number of individuals living with chronic diseases such as diabetes, heart disease, asthma, and obesity. Many live in multigenerational homes with large families and smaller spaces to social distance or isolate. There are new concerns with the winter months approaching and cough, cold, and flu season. As states enter Phase 3 of opening up more businesses and allowing larger public gatherings, there is a risk of new spikes in COVID-19 along with the flu as more people congregate indoors.

Over 5 million individuals identify themselves as American Indian and Alaska Native (AI/AN) alone or in combination with another race. Although they live worldwide, they are concentrated mostly in C.A., OK, AZ, TX, NM, WA, and N.Y. Under treaties and laws, the federal government should provide adequate health care services and water and sanitation. Unfortunately, in many cases, lack of access to clean water and plumbing and substandard housing, and crowded living conditions help spread the coronavirus. It has not been easy to wash hands frequently and practice social distancing. Only a small number of (AI/AN) live in Tribal areas. The majority are in rural communities. Because of lower socioeconomic levels and lack of private health insurance, most have depended on Indian Health Services to obtain funding from the government for testing and treatment. Some unrecognized tribes do not benefit from the federal government programs.

The Centers for Disease Control (CDC) and the Department of Health and Humans Services (DHHS) track the number of exposures, positive cases and tested by demographic data.

However, study after study document multiple errors in reporting the data. Federal, state, and local entities consistently omit crucial demographic information or racially misclassify AI/AN by grouping them in broad categories, such as "Other." Because of the incomplete, inaccurate, and unreliable data, COVID-19 cases were higher than reported. Urban Indian Health Institute, a Tribal Epidemiology Center, has created a new system to collect data with Indigenous values and practices. New proposed categories show designations as $\mathrm{AI} / \mathrm{AN}$ only, and $\mathrm{AI} / \mathrm{AN}$ in any combination of any race include those who identify as Latinx/Hispanic. Another important addition is to include the settings where COVID-19 patients reside, for example, long-term care facilities, jails and prisons, and homeless shelters where outbreaks have occurred.

Unfortunately, COVID-19 mortality data in Native populations have been incorrect too. Many studies show that medical examiners, coroners, and funeral home directors designate a disproportionate number of Native Americans as white because of subjective identification. It is their responsibility to contact the next of kin for proper identification.

Since April 2020, the APM research lab has been independently compiling, analyzing, and reporting COVID-19 deaths by race and ethnicity, from all states publicly releasing data in their study called the Color of Coronavirus project. There are gross disparities in "positive" cases and deaths among Black, Indigenous, Pacific Islander, and Latino Americans compared to White Americans. The data compiled by this group of researchers speak volumes on the need for more equality in healthcare services for the underserved community. There are 574 federally recognized tribes, and the pandemic has been devastating to the Native American Communities. Concerned for their plight, Treasury Secretary Steve Mnuchin was urged by concerned researchers to send federal aid. Under the $\$ 2$ trillion Coronavirus, Aid, Relief, and Economic Security (CARES) Act, $\$ 8$ billion was allocated to tribal governments to respond to the public health crisis. According to the John Hopkins Center for American Indian Health, distributed posters and materials about COVID-19, and the tribes imposed stay-at-home orders, curfews, and checkpoints to stop the virus's spread.

In a news report in the Los Angeles Times, May 1, 2020, in Albuquerque, NM, the governor sealed off all roads to nonessential traffic in Gallup to control the coronavirus outbreak affecting the trading post city and surrounding areas of the Navajo Nation. At that time, the Covid-19 infection rates were one of the worst hot spots for the pandemic, and the intensive care units were past capacity. The widespread infection in that community and the Mckinney at large and surrounding counties were linked to early infections at 


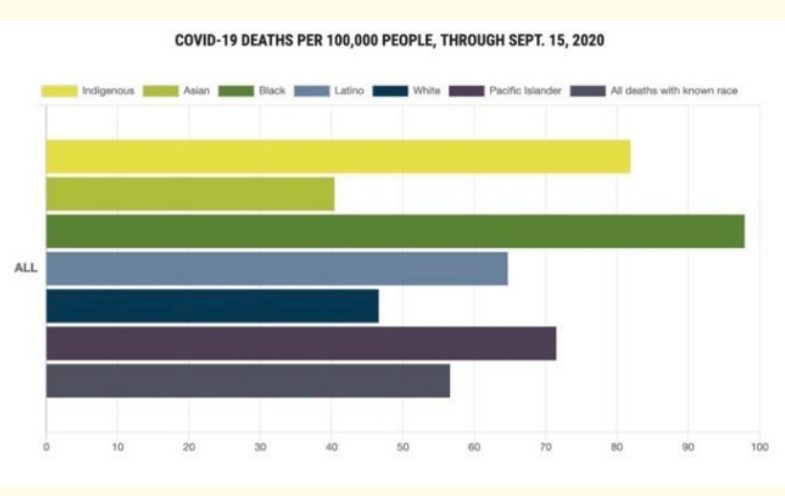

Figure 1

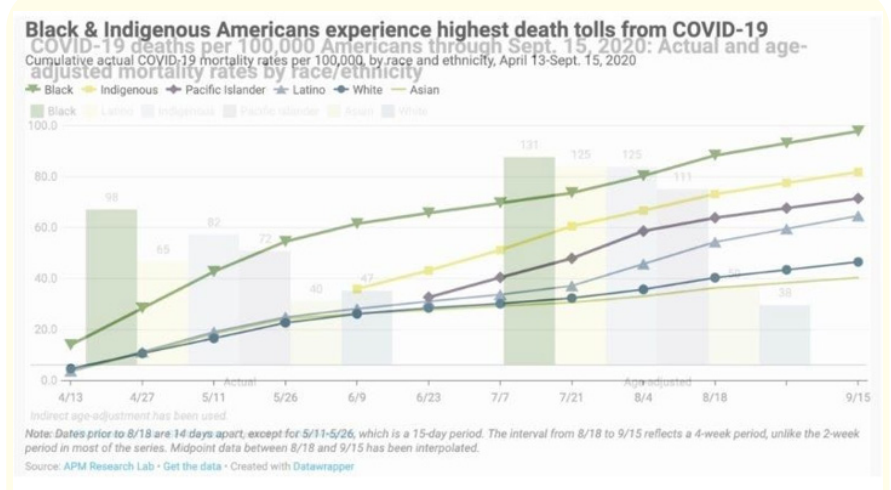

Figure 2

a drug treatment facility and later the homeless population. Unfortunately, social distancing and wearing masks challenged were by residents, even in stores. Because of significant safety concerns, the governor declared a state of emergency under the riot act and enacted curfews. Because of its location, Gallup's city is a communal place for the Navajo Nation and indigenous Zuni Pueblo to shop for household needs and liquor. The Navajo Nation also imposed curfews on the reservation, including sections New Mexico, Arizona, and Utah. At this time, McKinley County had at least 1,027 confirmed cases of COVID-19, which was more than $30 \%$ of all the cases in New Mexico. As of April 30, 2020, there were more than 3,607 confirmed cases of the coronavirus among Native Tribes, more than 2,000 of them on the Navajo reservation, according to Indian Services, which placed them third in having the highest rate of cases per capita, following New Jersey and New York. No one imaged that the positive case reported on March 17, 2020, was the beginning of a full-blown pandemic. As of September 20, 2020, the number of confirmed cases among the Navajo Nation was 11,540, 548 deaths, and 7,230 recovered.

The impact of Covid-19 on Native American communities has been a "double whammy" because by abiding by the government's health regulations and many tribal businesses have been halted. There is no single Indian casino open in the United States, and all tribal businesses are closed. By shutting down their casinos and other ventures, the negative economic impact has caused the loss of jobs for citizens in surrounding communities and decreased state tax revenue. According to Joseph Kalt, co-director of the Harvard Project on American Indian Economic Development, in 2019, the tribal gaming industry generated $\$ 17.7$ billion in taxes to federal, state, and local governments. Many tribes also offer governmental services on their land, but they cannot collect necessary taxes to pay for these services from their state and local governments. They depend on their businesses' revenue to pay for law enforcement, public safety, and social services. The Hualapai tribe, another casualty, had to close "The Skywalk," the horseshoe-shaped glassbottom walkway that extends over the Grand Canyon, which was significant revenue for the tribe. Even before the pandemic, most of the families lived below the poverty level. The median income for a Native American in the U.S. is about $\$ 39,700$, nearly a third less than the American household at \$57,600. Native American tribes' tax base is zero, and there are no funds to run the health clinic or child protection services. Throughout history, Native Americans have been resilient from numerous dark times.

Not only have businesses been impacted but also the ability to vote. San Juan County, New Mexico, reduced the number of voting locations from 32 to 9 . Although absentee voting is available, not all Navajo voters have a mailing address, and others do not understand the ballot instructions. For those who only speak Navajo, there are no translated instructions on the ballot, which is a disservice to those who want to vote but have limited resources [1-11]. 


\section{Conclusion}

In summary, most of the research's recurring themes are the disparities between the number of COVID-19 positive cases and deaths among Native Americans than other ethnic and racial groups and inaccuracies in reporting demographic data. As tribal businesses slowly open with limited capacity, there is hope for economic recovery for the Native people and surrounding communities.

\section{Bibliography}

1. Artiga S and Orgera K. "COVID-19 Presents Significant Risks for American Indian and Alaska Native People”. Kaiser Family Foundation Coronavirus (COVID- 19) (2020).

2. Astor M. For the Navajo Nation, 'Everything Takes Time,'Including Voting. Native Americans - The New York Times (2020).

3. Coronavirus disease 2019. Attribution-ShareAlike 3.0 Unported (CC BY-SA 3.0) (2020).

4. COVID-19 Coronavirus Tracker - Updated as of October 20. Kaiser Family Foundation (2020).

5. COVID-19 pandemic in the Navajo Nation-Wikipedia. COVID-19 Pandemic in the Navajo Nation Wikipedia (2020).

6. Hatcher SM., et al. "COVID-19 Among American Indian and Alaska Native Persons - 23 States, January 31 - July 3, 2020". Centers for Disease Control and Prevention (2020).

7. Hogan C. "Viruses". Viruses Encyclopedia of Earth (2012).

8. Lee K. "We're vulnerable": On the Navajo Nation, a rush to curb the coronavirus". Los Angeles Times (2020).

9. McPhillips D. “COVID-19's Tragic Effect on American Indians: A State- by-State Analysis. U.S. News and World Report" (2020).

10. The Color of Coronavirus: Response Panel - APM Research Lab. The Color of Coronavirus: COVID-19 Deaths By Race And Ethnicity In The U.S./APM Research Lab (2020).

11. The Impact of COVID-19 on Native American communities. The Harvard Gazette (2020).

\section{Assets from publication with us}

- Prompt Acknowledgement after receiving the article

- Thorough Double blinded peer review

- Rapid Publication

- Issue of Publication Certificate

- High visibility of your Published work

Website: www.actascientific.com/

Submit Article: www.actascientific.com/submission.php Email us: editor@actascientific.com

Contact uS: +919182824667

Citation: Phyllis M Weaver. "The Effects of COVID-19 on Native Americans". Acta Scientific Pharmaceutical Sciences 5.2 (2021): 27-30. 